\title{
Effectiveness of different entomopathogenic nematode species against the variegated cutworm, Peridroma saucia (Hubner) (Lepidoptera: Noctuidae)
}

\author{
Ebubekir Yuksel', Yunus Emre Taskesen, Duygu Erarslan and Ramazan Canhilal
}

\begin{abstract}
Peridroma saucia (Hubner) (Lepidoptera: Noctuidae) is a polyphagous pest that attacks nearly all vegetable fields in Turkey. Entomopathogenic nematodes (EPNs) are successfully used as a biological control agent. The efficacy of four EPNs, Steinernema carpocapsae, S. feltia. Heterorhabditis bacteriophora and H. indica against the last instar larvae of the pest, was tested under laboratory conditions. Suspensions of nematodes were applied at four concentrations $\left(10,50,100\right.$ and 200 infective juveniles/larva) at $25 \pm 1{ }^{\circ} \mathrm{C}$. Mortality percent was evaluated 48 and $96 \mathrm{~h}$ post application. Mortality rate increased with increasing concentrations. The highest effect caused $70 \%$ mortality by $\mathrm{H}$. bacteriophora and $\mathrm{H}$. indica species after $48 \mathrm{~h}$ exposure time and the lowest mortality was $33 \%$ for Steinernema carpocapsae. There was no significant difference between virulence of Heterohabditis spp. and Steinernema spp. when tested against the larvae of $P$. saucia after $96 \mathrm{~h}$ exposure time. These results showed that EPNs have a significant potential in the biological control of $P$. saucia under controlled conditions.
\end{abstract}

Keywords: Peridroma saucia, Variegated cutworm, Entomopathogenic nematode, Biological control

\section{Background}

The variegated cutworm (VCW), Peridroma saucia (Hubner, 1808) (Lepidoptera: Noctuidae), is a common polyphagous pest of many vegetable and field crops and found in many areas of the world (Rings et al., 1976 and Klein Koch and Waterhouse, 2000). VCW was first recorded in Europe in 1790 and then caused serious outbreaks in many countries throughout the Americas in 1841 (Capinera et al., 1988). The adults of these cutworms were discovered in 1967 in Turkey. At the present time, VCW is widely distributed in Turkey's agricultural areas and it is one of the most abundant and damaging cutworm species of Turkey (Akdagcik and Ulusoy, 2007). VCW has a wide range of host plants which includes economic crops such as potato, tomato, corn, lettuce, carrot and sugar beet. VCW larvae do much damage to crops and cause considerable mortality to seedlings in the early growing season by cutting off the plant at the soil surface and feeding on the

* Correspondence: ebubekiryuksel@erciyes.edu.tr Erciyes University, Kayseri, Turkey foliage of these crops (Capinera et al., 1988). Due to the high tolerance of VCW, repeated applications of conventional insecticides are widely used. Development of resistance and concerns over the destructive effects of chemicals to environmental and human safety have accelerated the development of alternative control methods for this pest (Yoshida, 2010).

Entomopathogenic nematodes (EPNs) are highly effective biological control agents against many agricultural pests particularly soil-inhabiting lepidopterous larvae because of their presence in larval stages below ground (Vashisth et al., 2013). EPNs have searching ability on hosts and the potential to survive in the soil environment. They possess free-living third-stage infective juvenile (IJ) that can survive a long time without feeding (Koppenhöfer et al., 2000). The IJs invade their hosts via natural body openings, such as the mouth, the anus and the spiracles. Once they enter to haemocoel, the mutualistic bacteria Xenorhabdus in Steinernema and Photorhabdus in Heterorhabditis are released to kill the host within 2 days (Gaugler, 2002; Griffin, et al., 2005; Kaya et al., 2006). 
EPNs that infect insects have received considerable attention by scientists for their potential in the biological management of many agricultural pests (Gaugler, 1981; Gaugler and Kaya, 1990; Georgis et al., 2006; Koppenhöfer et al., 2000; Smart Jr, 1995). Many studies have been started for testing the pathogenicity of these indigenous EPN species all over the world (Ozer et al., 1995; Kepenekci, 2002; Hazir et al., 2003; Unlu et al., 2007 and Erbas et al., 2013). There are some differences known in terms of survival, pathogenicity and host range between indigenous and non-indigenous EPN species (Lacey and Georgis, 2012). Indigenous species of EPNs may be more successful in biocontrol as a consequence of compatibility to native habitats (Goudarzi et al., 2015).

The aim of this study is to evaluate the effect of four Turkish species of EPNs for the biological control of the variegated cutworm (VCW), P. saucia, under laboratory conditions.

\section{Materials and methods Insect culture}

Healthy VCW larvae were collected on a regular basis from different vegetable fields throughout the vicinity of Central Anatolia and Mediterranean Region, Turkey. For the experiment, larvae were reared on lettuce. $P$. saucia was established in a growth chamber at a temperature of $25 \pm 1{ }^{\circ} \mathrm{C}$, relative humidity of $60 \%$ and a photoperiod of 16:8 (L:D) (Scott-Dupree et al., 2008). Healthy last instar larvae were selected to be used for testing the virulent effects of the nematodes in a doseresponse experiment.

\section{Entomopathogenic nematodes}

Four indigenous nematode isolates of Heterorhabditis bacteriophora FLH-3-H, H. indica 216-H, Steinernema feltiae Y29-S and S. carpocapsae E76-S were collected during the surveys conducted in Adana and Kahramanmaras provinces in the Mediterranean region of Turkey.

\section{Pathogenicity test}

Nematode pathogenicity was tested against last instar larvae of $P$. saucia in a Petri dish arena. In order to avoid cannibalism, only one last instar larva was placed on two moist filter papers in each $100 \times 15 \mathrm{~mm}$ Petri dish inoculated with $1 \mathrm{ml}$ of water containing different concentrations of IJs (10, 50, 100 and $200 \mathrm{IJs} /$ larva). Each nematode concentration was tested against ten $P$. saucia larvae and replicated for three times. Control plates were treated with distilled water only. Petri dishes were kept at $25 \pm 1{ }^{\circ} \mathrm{C}$. The number of dead larvae was recorded at two different exposure times (48 and $96 \mathrm{~h}$ ) and dead insects were dissected to determine whether nematodes were present or not.

\section{Statistical analysis}

Data was evaluated without being regulated by the Abbott formula because there was no mortality in control plates (Abbott, 1925). Statistical analyses were carried out by SAS software (Version 9.1.3; SAS Institute, Cary, NC (1990)). The experiment was established in a completely randomized design with a factorial treatment arrangement consisting of four nematode species and four application rates. Mean values were separated using Tukey Multiple Range Test $(P<0.05)$.

\section{Results and discussion}

The virulence of four indigenous nematode species against last larval instar of $P$. saucia was evaluated in a laboratory experiment. Results revealed that all EPN species had the ability to kill and reproduce in $P$. saucia larvae by sickening them. All EPN species tested and application concentrations significantly affected the mortality rates $(F: 27.85, d f: 3, P<0.001$ for EPN species and $F: 18.12, d f: 3, P<0.001$ for application of the tested concentrations after $48 \mathrm{~h} ; F$ : 5.14, $d f: 3, P<0.05$ for EPN species and $F: 1.30$, $d f$ : $3, P<0.05$ for application of concentrations after 96 h). No significant differences were noted statistically in mortality rates caused by the concentrationsnematode interaction.

Mortality rates have increased generally with increasing concentrations. $H$. bacteriophora and $H$. indica strains showed higher effects at all application concentrations than $S$. feltiae and $S$. carpocapsae strains at the first exposure time $(48 \mathrm{~h})$ except $H$. indica and $S$. carpocapsae at $10 \mathrm{IJs} /$ larva concentrations. The highest larval mortality was achieved when EPNs were applied at the concentrations of $200 \mathrm{IJs} /$ larva after $48 \mathrm{~h}$ (Table 1). However, after the second exposure time ( $96 \mathrm{~h}$ ), generally no differences were found among strains except 10 IJs/larva concentrations.

All EPN species tested showed a great mortality at the lowest concentration of $10 \mathrm{IJs} /$ larva after $96 \mathrm{~h}$ of exposure time and at least $80 \%$ of $P$. saucia were killed by $S$. feltiae Y29-S strain. The difference in mortality between $H$. bacteriophora FLH-3-H (100\%) and S. feltiae Y29-S (80\%) was statistically significant. At the exposure time of $48 \mathrm{~h}$, the highest mortality rate was induced by $H$. indica isolate, while the lowest one was determined by $S$. carpocapsae isolate at the concentrations of 10 and $50 \mathrm{IJs} /$ larva. Only the mortality produced by $S$. carpocapsae E76-S was different than the one by $H$. indica $216-\mathrm{H}$ significantly at the concentration of $10 \mathrm{IJs} /$ larva, but at $50 \mathrm{IJs} /$ larva concentrations, they were divided into two groups which statistically differed when compared to each other. The interaction effect of the different entomopathogenic species and the concentrations on 
Table 1 The effect of different concentrations of EPNs on the mortality of last instar larvae of $P$. saucia for 48 and 96 h post application at $25 \pm 1{ }^{\circ} \mathrm{C}$

\begin{tabular}{|c|c|c|c|c|c|c|c|c|}
\hline \multirow[t]{3}{*}{ EPNs } & \multicolumn{8}{|c|}{ Mortality rates of $P$. saucia larvae ${ }^{a}$} \\
\hline & \multicolumn{2}{|l|}{$10^{\mathrm{b}}$} & \multicolumn{2}{|l|}{$50^{b}$} & \multicolumn{2}{|l|}{$100^{b}$} & \multicolumn{2}{|l|}{$200^{b}$} \\
\hline & $48 \mathrm{~h}$ & $96 \mathrm{~h}$ & $48 \mathrm{~h}$ & $96 \mathrm{~h}$ & $48 \mathrm{~h}$ & $96 \mathrm{~h}$ & $48 \mathrm{~h}$ & $96 \mathrm{~h}$ \\
\hline H.b.FLH-3-H & $26.66 a b$ & 100.00a & $66.66 a$ & 100.00a & $86.66 a$ & 100.00a & 100.00a & $100.00 \mathrm{a}$ \\
\hline S.f. Y29-S & $20.00 a b$ & $80.00 \mathrm{~b}$ & $26.66 b$ & $100.00 a$ & $33.33 b$ & $100.00 a$ & $66.66 b$ & $100.00 \mathrm{a}$ \\
\hline S.c. E76-S & $13.33 b$ & 93.33ab & $13.33 b$ & 100.00a & $40.00 \mathrm{~b}$ & 100.00a & $66.66 b$ & 100.00a \\
\hline H. i. $216-H$ & 33.33a & $93.33 a b$ & $73.33 a$ & 100.00a & 73.33a & 100.00a & 100.00a & $100.00 \mathrm{a}$ \\
\hline
\end{tabular}

H.b.FLH-3-H, Heterorhabditis bacteriophora FLH-3-H isolate; S.f. Y29-S, Steinernema feltiae Y29-S isolate; S.c. E76-S, S. carpocapsae E76-S isolate; H. i. 216-H, H. indica $216-\mathrm{H}$ isolate

${ }^{a}$ Mean values followed by different lowercase letters in the same column are significantly different according to Tukey's test $(P<0.05)$

${ }^{\mathrm{b}}$ The number of infective juveniles for each larva

larval infection were not significant after exposure for $96 \mathrm{~h}$ at 50, 100 and $200 \mathrm{IJs} / \mathrm{larva}$. The most virulent species was $H$. bacteriophora at the lowest IJ concentration of $100 \%$ mortality after $96 \mathrm{~h}$ of exposure time followed by $S$. carpocapsae and $H$. indica with $93.3 \%$ mortality (Table 1 ).

S. carpocapsae and S. feltiae caused equal mortality in the last instar larvae which was less virulent than $H$. bacteriophora and $H$. indica, at a concentration of 200 IJs/larva over the exposure time of $48 \mathrm{~h}$ (Table 1).

In a laboratory experiment, Heterorhabditis spp. proved to be more efficient in suppressing $P$. saucia. Increase in the time of exposure caused more mortality to last instar $P$. saucia larvae by all the tested nematode species (Table 1). Similar studies have been carried out to evaluate the effectiveness of EPNs against $P$. saucia larvae where it was revealed that EPNs have great potential for the management of $P$. saucia larvae (Yoshida, 2010; Morris and Converse, 2012). The pathogenicity of steirnematid and heterorhabditid nematode species against $P$. saucia larvae was variable in previous studies. Morris and Converse (2012) exposed P. saucia larvae to six strains of steirnematid and two species of heterorhabditid nematodes in the soil surface. S. feltiae was found as the most virulent nematodes while the heterorhabditid nematodes were the best performing species in our study. The pathogenicity of 17 Japanese isolates of EPNs was tested against the middle instar larvae of $P$. saucia in a laboratory experiment at different temperatures. Three isolates belonging to $S$. feltiae caused $70 \%$ average mortality at $25{ }^{\circ} \mathrm{C}$ which is similar to our study (Yoshida, 2010).

\section{Conclusions}

Under laboratory conditions in the petri dish experiment, the heterorhabditid nematodes proved a more effective control of $P$. saucia larvae and increase in time of exposure led to more mortality of the tested nematode species. More studies are needed to determine the real potential of these four indigenous EPNs both in the open field and greenhouse environments to be included in biological control programs of $P$. saucia.

\section{Authors' contributions}

EY carried out the laboratory studies and drafted the manuscript. All authors read and approved the final manuscript.

\section{Competing interests}

The authors declare that they have no competing interests.

\section{Publisher's Note}

Springer Nature remains neutral with regard to jurisdictional claims in published maps and institutional affiliations.

Received: 7 July 2017 Accepted: 6 December 2017

Published online: 30 January 2018

\section{References}

Abbott WS (1925) A method of computing the effectiveness of an insecticide. J Econ Entomol 18:265-267

Akdagcik Z, Ulusoy MR (2007) Insect pests on broccoli (Brassica oleracea L. Var. italica) in Cukurova region. JAgric Fac CU 22(1):119-124

Capinera JL, Pelissier D, Menout GS, Epsky ND (1988) Control of black cutworm, Agrotis ipsilon (Lepidoptera: Noctuidae), with entomogenous nematodes (Nematoda: Steinernematidae, Heterorhabditidae). J Invertebr Pathol 52(3): 427-435

Erbas Z, Gokce C, Hazir S, Demirbag Z, Demir I (2013) Isolation and identification of entomopathogenic nematodes (Nematoda:Rhabditida) from the eastern Black Sea region and their biocontrol potential against Melolontha melolontha (Coleoptera: Scarabaeidae) larvae. Turk J Agric For 38(2):187-197

Gaugler R (1981) Biological control potential of neoaplectanid nematodes. J Nematol 13(3):241

Gaugler R (2002) Entomopathogenic nematology. CABI Publishing, Wallingford, 393

Gaugler R, Kaya HK (1990) Entomopathogenic nematodes in biological control. CRC press, Boca Raton, 365

Georgis R, Koppenhöfer AM, Lacey LA, Belair G, Duncan LW, Grewal PS, Samish M, Tan L, Torr P, Van Tol RWHM (2006) Successes and failures in the use of parasitic nematodes for pest control. Biol Control 38:103-123

Goudarzi M, Moosavi MR, Asadi R (2015) Effects of entomopathogenic nematodes, Heterorhabditis bacteriophora (Poinar) and Steinernema carpocapsae (Weiser), in biological control of Agrotis segetum (Denis \& Schiffermuller)(Lepidoptera: Noctuidae). Turk entomol derg 39(3):239-250

Griffin CT, Boemare NE, Lewis EE (2005) Biology and behaviour. In: Grewal PS, Ehlers R-U, Shapiro-llan DI (eds) Nematodes as biocontrol agents, pp. 47-64 CAB International Pubs, Wallingford, p 479

Hazir S, Kaya HK, Stock SP, Keskin N (2003) Entomopathogenic nematodes (Steinernematidae and Heterorhabditidae) for biological control of soil pests. Turkish J Biol 27(4):181-202 
Kaya HK, Aguillera MM, Alumai A, Choo HY, De la Torre M, Fodor A, Ganguly S, Hazir S, Lakatos T, Pye A, Wilson M, Yamanaka S, Yangm H, Ehlers RU (2006) Status of entomopathogenic nematodes and their symbiotic bacteria from selected countries or regions of the world. Biol Control 38:134-155

Kepenekci I (2002) Entomopathogenic nematodes (Rhabditida) in the Mediterranean region of Turkey. Nematol Mediterr 30:13-15

Klein Koch C, Waterhouse DF (2000) The distribution and importance of arthropods associated with agriculture and forestry in Chile. ACIAR Monograph No. 68, Canberra, p 234

Koppenhöfer AM, Ganguly S, Kaya HK (2000) Ecological characterisation of Steinernema monticolum, a cold-adapted entomopathogenic nematode from Korea. Nematology 2(4):407-416

Lacey LA, Georgis R (2012) Entomopathogenic nematodes for control of insect pests above and below ground with comments on commercial production. J Nematol 44:218-225

Morris ON, Converse V (2012) Effectiveness of steinernematid and heterorhabditid nematodes against noctuid, pyralid, and geometrid species in soil. Can Entomol 123(1):55-61

Ozer N, Keskin N, Kirbas Z (1995) Occurrence of entomopathogenicnematodes (Steinernematidae and Heterorhabditidae) in Turkey. Nematologica 41:639-640 Rings RW, Johnson BA, Arnold FJ (1976) Host range of the variegated cutworm on vegetables: a bibliography. Bull Entomol Soc Am 22(4):409-415

SAS (1990) SAS/STAT user's version 6, 4th edition, vol 1 \& 2. SAS Institute Inc, Cary Scott-Dupree CD, Harris CR, Moineddin M, Leboeuf J (2008) Flight activity and susceptibility to insecticides of variegated cutworm, Peridroma saucia (Hubner) attacking field tomoatoes in southwestern ontario. J Entomol Soc Ont 139:19-25

Smart GC Jr (1995) Entomopathogenic nematodes for the biological control of insects. J Nematol 27(4S):529

Unlu IO, Ehlers R-U, Susurluk IA (2007) Additional data and first record of entomopathogenic nematode Steinernema weiseri from Turkey. Nematology 9:739-741

Vashisth S, Chandel YS, Sharma PK (2013) Entomopathogenic nematodes-a review. Agri Rev 34(3):163-175

Yoshida M (2010) Influence of temperature on pathogenicity of some entomopathogenic nematode isolates (Steinernema spp.) from Japan screened for ability to control some noctuid moth larvae. Jpn J Nematol 40(2):27-40

\section{Submit your manuscript to a SpringerOpen ${ }^{\circ}$ journal and benefit from:}

- Convenient online submission

- Rigorous peer review

- Open access: articles freely available online

- High visibility within the field

- Retaining the copyright to your article

Submit your next manuscript at $\boldsymbol{\nabla}$ springeropen.com 